Methods explained is a quarterly series of short articles explaining statistical issues and methodologies relevant to ONS and other data. As well as defining the topic areas, the notes explain why and how these methodologies are used. Where relevant, the reader is also pointed to further sources of information.

\title{
The Balance of Payments
}

\author{
Graeme Chamberlin
}

\section{Office for National Statistics}

\section{SUMMARY}

This article describes the main features of the United Kingdom Balance of Payments. The Balance of Payments essentially records one nation's transactions with the rest of the world - relating to conventional trade in goods and services, income flows and the transfer in ownership of financial assets across borders. The International Investment Position, or net asset position, is the part of the Balance of Payments that records net stocks of the UK's foreign assets and liabilities. The relationship between this and investment income is also analysed. Finally, the impact of the global recession and credit crunch on recent Balance of Payments data is presented.

T he Balance of Payments records one nation's transactions with the rest of the world. This not only includes the conventional flows of goods and services that make up international trade, but also cross-border payments associated with the international ownership of financial assets and current transfers, including remittances by workers from one country to another. In fact, remittances have become increasingly important in recent decades as capital and labour becomes increasingly mobile and financial markets in different countries more strongly integrated. Therefore the means of production are becoming just as likely to move across borders as the actual goods and services produced.

The purpose of this article is to outline the main structure of the UK Balance of Payments so the reader can understand how international trade in goods, services and financial assets and cross-border income flows are recorded in the National Accounts ${ }^{1}$. In doing this the changing patterns over time are presented, along with a more recent analysis of how the current global economic downturn is being reflected in key parts of the Balance of Payments.

The Balance of Payments can effectively be broken down into two parts. The Current Account records international trade in goods and services, international income flows and current transfers. The Capital Account and Financial Account form the counter part to this, recording the changing pattern in the international ownership of assets. While the Financial Account records changes in the cross-border flows of assets the International Investment Position measures the total stocks of foreign assets and liabilities held by a nation. Some features of this, in particular its relation to investment income, are also analysed in this article.

\section{Current Account}

The Current Account consists of four parts:

- Trade in goods

- Trade in services

- Net income flows

- Current transfers

Table 1 presents the UK Current Account for 2007. Although data for 2008 are available these have been significantly affected by the turmoil in the global financial markets and the world recession so are not the best to use for demonstration purposes.

The trade in goods balance is the difference between the value of goods exported and the value of goods imported. Hence, in 2007 a $£ 220.9$ billion credit to the Current Account resulted from goods exports and a $£ 310.6$ billion debit from imports giving an overall deficit of $£ 89.8$ billion. The trade in services is recorded in the same way, with credits to the Current Account reflecting services exports and debits services imports. In 2007 the UK ran an overall surplus of $£ 44.8$ billion on the balance of trade in services.

An often cited measure is the trade balance which is the overall balance in the trade in goods and services. In 2007 this would have been negative to the tune of $£ 45$. 0 billion, as the deficit in goods trades outweighs the surplus in services trade. The trade balance though is not to be confused with the overall Current Account which consists of two further, but less well-known, items.

Net income flows reflect international payments associated with the ownership of the factors of production (land, labour and capital).

Two types of income transactions are distinguished; compensation of employees which is paid to non-resident workers involved in the

Table 1

UK Current Account in 2007

\begin{tabular}{lrrr} 
& & & f billions \\
\hline Goods trade & Credit & Debit & Balance \\
Services trade & 220.9 & 310.6 & -89.8 \\
Net income flows & 150.6 & 105.8 & 44.8 \\
Current transfers & 291.3 & 270.5 & 20.8 \\
Current Account (total) & 14.0 & 27.6 & -13.5 \\
\hline & 676.8 & 714.6 & -37.7 \\
\hline
\end{tabular}

Source: ONS Balance of Payments 
production process and investment income which is the return for providing financial assets and rent for natural resources.

In 2007 net compensation of employees debits (outflows) exceeded credits (inflows) by $£ 734$ million. However, this clearly accounts for only a small proportion of the total given UK net income was $£ 20.8$ billion in surplus in 2007 .

The remainder of net income relates to investment income - these are the payments associated with the international ownership of financial assets such as interest payments and dividends. For example, if a UK citizen owned shares in a foreign company, then any dividends earned from this would be counted as a credit. Alternatively, if a UK company borrowed money from a foreign bank then any interest payments accrued would be recorded as a debit.

As financial markets around the world become increasingly integrated it is likely that residents (households, firms, financial institutions such as banks and pension funds, non-profit institutions and the public sector) in one country will seek to diversify their portfolios of financial assets to take advantage of higher returns overseas and reduce exposures to individual country risks. Therefore the ownership of foreign assets and foreigner's ownership of UK assets have grown rapidly and investment income flows are becoming a major determinant of the Current Account.

Current transfers are the final component of the Current Account. This records a miscellaneous set of net payments including workers remittances, social security, foreign aid and contributions to international organisations such as the European Union (EU). As Table 1 shows, these flows are small compared to other parts of the Current Account and in 2007 were in overall deficit of $£ 13.5$ billion.

\section{Current Account - some history}

In sum the UK Current Account deficit was $£ 37.7$ billion or 2.7 per cent of Gross Domestic Product (GDP) in 2007. The longer-term history of the UK Current Account and its main components are presented in Table 2, and here it can be clearly seen that the overall UK Current Account has been predominately in deficit over the last 40 years.

Table 2

\section{The UK Current Account and its main components}

\begin{tabular}{lrrrrr} 
& \multicolumn{5}{c}{ Percentage of GDP (five year averages except later years) } \\
\hline Year & $\begin{array}{r}\text { Goods } \\
\text { trade }\end{array}$ & $\begin{array}{r}\text { Services } \\
\text { trade }\end{array}$ & $\begin{array}{r}\text { Net } \\
\text { income }\end{array}$ & $\begin{array}{r}\text { Current } \\
\text { transfers }\end{array}$ & $\begin{array}{r}\text { Current } \\
\text { Account }\end{array}$ \\
\hline $1955-59$ & -0.4 & 0.4 & 0.8 & 0.0 & 0.9 \\
$1960-64$ & -0.9 & 0.1 & 0.9 & -0.1 & 0.0 \\
$1965-69$ & -0.9 & 0.4 & 0.8 & -0.2 & 0.0 \\
$1970-74$ & -2.1 & 1.2 & 0.9 & -0.3 & -0.3 \\
$1975-79$ & -2.0 & 2.2 & -0.1 & -0.6 & -0.5 \\
$1980-84$ & 0.1 & 1.8 & -0.6 & -0.5 & 0.7 \\
$1985-89$ & -3.1 & 1.8 & -0.4 & -0.7 & -2.4 \\
$1990-94$ & -2.1 & 1.1 & -0.4 & -0.7 & -2.1 \\
$1995-99$ & -2.1 & 1.7 & 0.2 & -0.8 & -1.0 \\
$2000-04$ & -4.2 & 1.9 & 1.2 & -0.8 & -2.0 \\
2005 & -5.5 & 2.1 & 1.7 & -0.9 & -2.6 \\
2006 & -5.8 & 2.6 & 0.7 & -0.9 & -3.3 \\
2007 & -6.4 & 3.2 & 1.5 & -1.0 & -2.7 \\
2008 & -6.4 & 3.8 & 1.9 & -0.9 & -1.7 \\
\hline
\end{tabular}

Source: ONS Balance of Payments
The main factor behind the UK's persistent Current Account deficit has been the deficit on the balance of trade in goods. In fact, since 1946 this has been in deficit every year bar five. An average surplus was recorded between 1980-84 when UK goods trade was aided by North Sea oil production and high oil prices, but since then the deficit has consistently grown as a proportion of GDP to 6.4 per cent in both 2007 and 2008 .

As manufacturing goods make up the largest proportion of goods trade then the relative decline in UK manufacturing output might suggest why this deficit has grown over the last two decades. The emergence of low cost producers in emerging markets have meant that the bulk of UK manufacturing including automobiles, clothing and footwear, consumer electronics and materials processing have seen its global market share fall. However, the UK has managed to increase its export share in smaller higher technology manufactures such as medical and pharmaceuticals, communications equipment, office machinery and computers.

On the other hand exports of services have exceeded imports every year since 1951 except two, and surpluses as a proportion of GDP have grown continuously since EU membership in 1973. This is consistent with the changing composition of UK output, with the largest surpluses in financial and business services - and is evidence that structural change in the UK economy has followed its comparative advantage in international trade ${ }^{2}$.

Net income has been more erratic over the years reflecting the inherent volatility in financial markets. It was last negative as recently as 1999 due to the impact of the Asian financial crisis, but during the last decade has generally made a positive contribution to the Current Account.

In comparison current transfers have made a negative contribution to the Current Account but the deficit has been fairly stable as a proportion of GDP over the last 30 years. The typical deficit reflects net contributions to the $\mathrm{EU}$ and the cost of foreign aid.

\section{Capital and Financial Accounts}

So what does it mean if the UK ran a Current Account deficit of $£ 37.7$ billion in 2007? Basically it states that foreigners are adding to their stock of UK assets by a sum of $£ 37.7$ billion more than UK residents are adding to their stock of foreign assets - or that the UK is essentially increasing its net liabilities to the rest of the world by this amount.

The Capital and Financial Accounts records the counterparts to the Current Account, which are the offsetting changes in the ownership of financial assets as implied by the Current Account surplus or deficit. In fact, Table 3 shows that in 2007 both UK residents have added to their stock of foreign assets and foreign residents have added to their stock of UK assets by over $£ 1,000$ billion ( $£ 1$ trillion) - but the key is that foreigners have added to their stock of assets by somewhat ( $£ 37.7$ billion) more.

In Table 3 the credit column refers to money spent by foreign residents on UK assets and the debit column to money spent by UK residents on foreign assets.

The Capital Account consists of several miscellaneous items such as 
Table 3

UK Capital and Financial Accounts in 2007

\begin{tabular}{lrrr} 
& & & $\mathrm{f}$ billions \\
\hline Capital Account & Credit & Debit & Balance \\
Financial Account & 4.6 & 2.0 & 2.6 \\
Direct investment & & & \\
Portfolio investment & 98.2 & 136.1 & -38.0 \\
Other investment & 203.3 & 92.0 & 111.3 \\
Total & 725.9 & 767.5 & -41.6 \\
& 1027.4 & 995.7 & 31.7 \\
Balancing item & & & 3.4 \\
Grand total & & & 37.7 \\
\hline
\end{tabular}

Source: ONS Balance of Payments

Table 4

\section{Major direct investment acquisitions by/of UK companies in the last decade by value}

\author{
Outwards acquisitions of foreign companies \\ f113.0 billion: Mannesmann AG by Vodafone (2000 Q1) \\ f37.5 billion: Airtouch by Vodafone (1999 Q2) \\ £32.6 billion: Amoco Corp by British Petroleum (BP) (1998 Q4) \\ f21.0 billion: Zeneca PLC by Astra AB (1999 Q2) \\ f18.5 billion: Alcan Inc by Rio Tinto (2007 Q4) \\ f18.0 billion: Atlantic Richfield by BP Amoco (2000 Q2) \\ f9.3 billion: Altadis SA by Imperial Tobacco Group (2008 Q1) \\ f9.1 billion: Household International by HSBC (2003 Q1) \\ f7.7 billion: Medlmmune Inc by AstraZeneca (2007 Q3) \\ f6.6 billion: Credit Commerciale de France by HSBC (2000 Q3) \\ f5.8 billion: Charter 1 by Royal Bank of Scotland (RBS) (2004 Q3) \\ f5.5 billion: Hutchison Essar by Vodafone Group (2007 Q2) \\ f5.0 billion: Innovene Inc by Ineos Group (2005 Q4)
}

\section{Inward acquisitions of UK companies}

f23.5 billion: Orange PLC by France Telecom (2000 Q3)

f19.5 billion: Orange PLC by Mannesmann AG (1999 Q4)

f17.7 billion: 02 by Telefonica (2006 Q1)

f12.5 billion: British Energy by Electricite de France (EDF) (2009 Q1)

f11.0 billion: Alliance Boots PLC by AB Acquisitions Ltd

f10.1 billion: British Airports Association (BAA) by Ferrovial (2006 Q2)

f9.0 billion: Abbey National by Banco Santander (2004 Q4)

f8.5 billion: Reuters Group by Thomson Corporation (2008 Q2)

f8.3 billion: Hanson PLC by Heidellberg Cement AG (2007 Q3)

f8.2 billion: BOC Group PLC by Linde AC (2006 Q3)

f8.1 billion: Imperial Chemical Industries by AKZO Nobel (2008 Q1)

f7.5 billion: Scottish \& Newcastle by Sunrise Acquisitions Ltd (2008 Q2)

f6.7 billion: ASDA by Wal-Mart (1999 Q3)

f5.3 billion: Amersham PLC by General Electric Group (2004 Q2)

£5.2 billion: Powergen by E.on (2002 Q3)

Source: ONS Balance of Payments

land purchases and sales associated with embassies, the transfers of migrants, EU regional development fund payments and so on. It is small relative to the Financial Account, and in 2007 credits exceeded debits by $£ 2.6$ billion.

The Financial Account has been broken down according to the main types of assets.

Direct investments refer to the purchase by the residents of one country of a significant part of an enterprise in another country. This not only consists of factories or production units but larger shareholdings (in excess of 10 per cent of total equity) which is considered to give the owner influence over the management of the enterprise and the set level of dividends.
The purchase of British Airports Association (BAA) by the Spanish company Ferrovial and British Energy Group by Electricite de France (EDF) are examples of direct investment credits in the Financial Account. Likewise, the purchase of the German telecoms firm Mannesmann by Vodafone and Atlantic Richfield by BP Amoco would be examples of significant direct investment debits. Major (in excess of $£ 5$ billion) direct investment acquisitions of foreign companies by UK companies and vice-versa during the last ten years are recorded in Table 4.

Portfolio investments relate to the smaller purchases of equity (less than 10 per cent of the total) and also debt securities.

Other investments in the main refer to financial intermediation services. For example, a deposit made by a UK local authority in an Icelandic bank would have been scored as a debit. Alternatively a loan from a foreign bank to a UK household would be classified as a credit.

The sums recorded in both the debit and credit columns in the other investment category are huge, representing around 70 per cent of UK Gross Domestic Product. This is because the UK financial system is highly integrated with the rest of the world's financial markets and plays a large intermediary role between them.

For example, a UK bank may receive $£ 1$ billion in deposits from a German pension fund that it then lends to US firms. In this case both the credit and debit columns of the other investment category will increase by $£ 1$ billion. Alternatively the UK bank may decide to lend the $£ 1$ billion to a UK firm that purchases a majority shareholding in a foreign company. In this case the debit column in the other investment category and the credit column in the direct investment category will both increase by $£ 1$ billion. Because these types of intermediary transactions are so commonplace it is easy to understand how the size of credits and debits in the Financial Account may be a large proportion of GDP but the difference between them is relatively small. This is demonstrated in Figure 1, where both foreign assets and liabilities (holdings of UK assets by foreigners) have grown significantly as a proportion of GDP yet in each year differ by a relatively small amount.

The final element, which does not officially form part of the Capital or Financial Accounts is the balancing item. Although in theory the Capital and Financial Accounts should offset the Current Account,

\section{Figure 1}

Net acquisitions of financial assets and liabilities Percentage of GDP

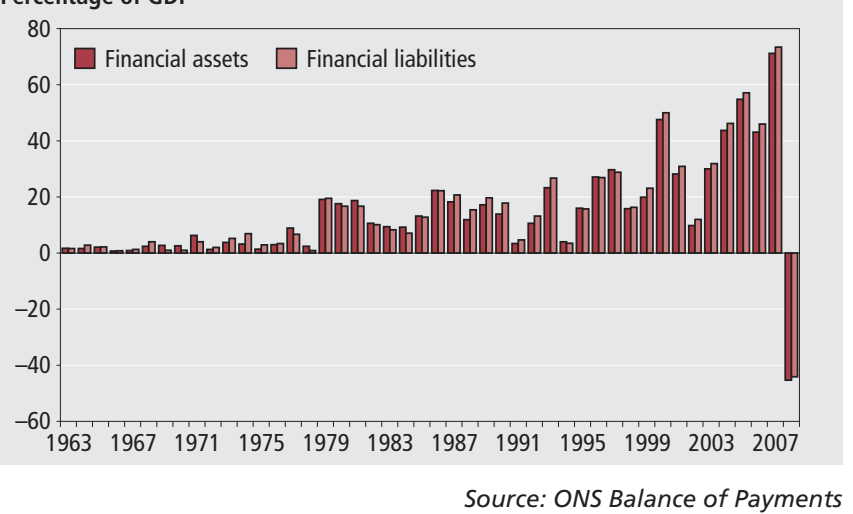




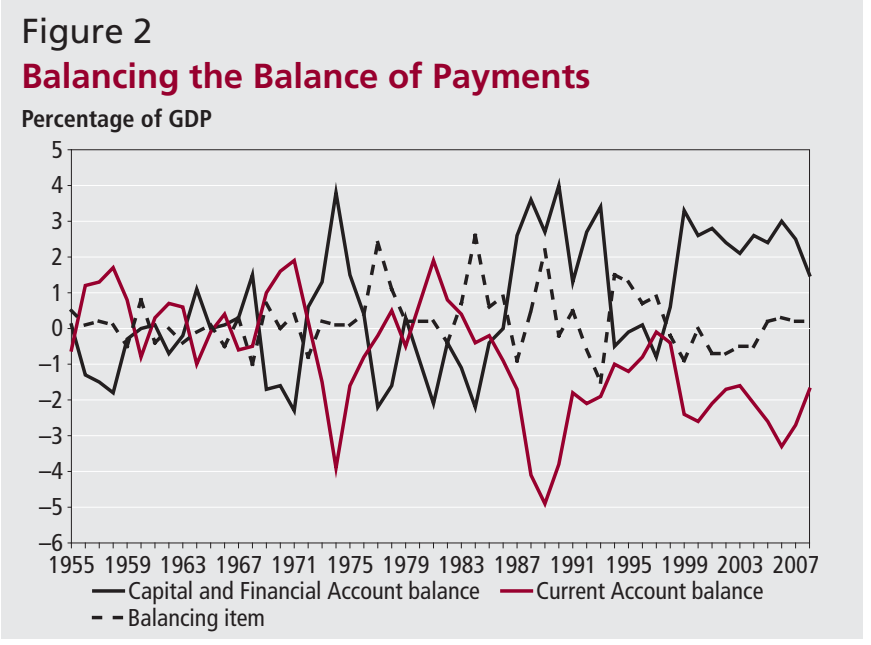

Source: ONS Balance of Payments

\section{Figure 3}

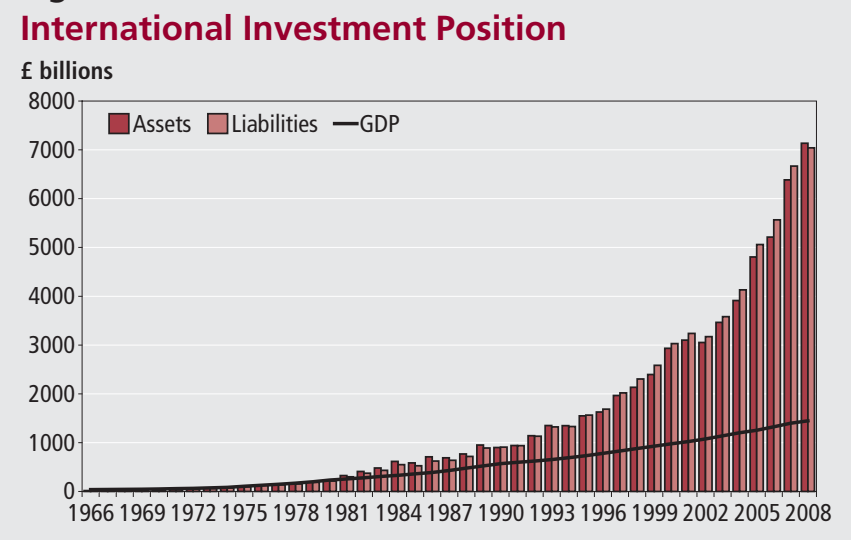

Source: ONS Balance of Payments

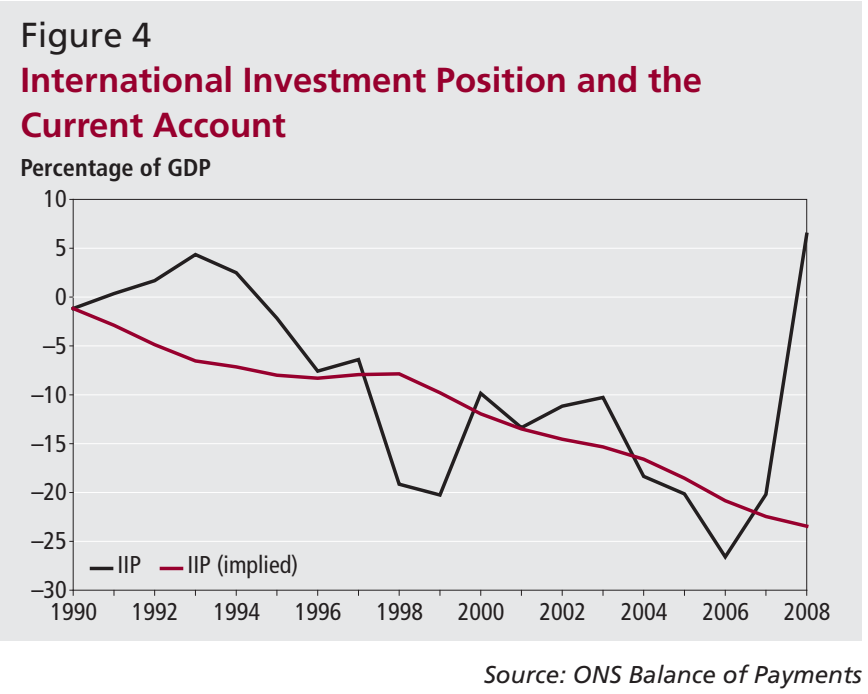

in practise it rarely does due to errors and omissions. The purpose of the balancing item is therefore reconcile the two sides of the Balance of Payments.

Figure 2 shows the long-term history of the UK Current Account balance, the Capital and Financial Accounts balances, and the balancing item as a percentage of GDP. Clearly there is an offsetting relationship between the two main parts of the Balance of Payments, so the data behaves as expected. The balancing item exhibits some volatility but in recent years has been relatively minor.

\section{International Investment Position}

While the Financial Account records international flows in the acquisition and disposals of financial assets the stock positions are presented in the International Investment Position (IIP). This is the difference in the value of foreign assets held by UK residents (UK's foreign assets) and UK assets held by foreign residents (UK's foreign liabilities). Therefore it is also referred to as the net-asset position.

Like Financial Account flows in Figure 1, the UK's stocks of foreign assets and liabilities have grown rapidly and now far outstrip GDP. As Figure 3 shows, stocks of foreign assets and liabilities are near

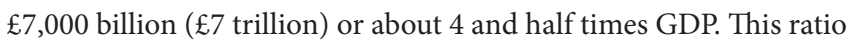
is much higher than in most developed countries (for the US stocks of foreign assets and liabilities were around 100 per cent of GDP in 2005) and is a strong indication of the relative openness of the UK economy, and in particular its financial sector, to the rest of the world.

And like the balance on the Financial Account, in any one year the IIP or net asset position is relatively small given the size of the asset stocks, further indication of the intermediary role played by UK financial institutions in the global economy.

As the IIP and Financial Account are linked by a stock-flow relationship, in theory, there should also be a relationship between the IIP and the Current Account. The UK's persistent Current Account deficit over the last thirty years implies that the nation has been living beyond its means for a considerable period of time requiring offsetting surpluses on the Financial Account. Therefore, as this feeds through into asset stocks it would be expected that a long run decline in the IIP would result.

Figure 4 plots the actual UK IIP since 1990, and the IIP implied by the accumulation of Current Account deficits. Up until 2007 the IIP has generally behaved as expected, deteriorating in line with Current Account deficits. However, in 2008 the IIP jumped sharply into positive territory for the first time since 1994.

This can be explained by looking at what determines the actual dynamics of the IIP between time period $(\mathrm{t})$ and $(\mathrm{t}-1)$ :

$\operatorname{IIP}(\mathrm{t})=\operatorname{IIP}(\mathrm{t}-1)+$ Current Account $(\mathrm{t})+$ asset revaluations $(\mathrm{t})$

where asset revaluations $=$ price changes + exchange rate changes + other adjustments

That is changes in the net asset position do not just reflect Financial (Current) Account flows but also revaluations of those assets. Furthermore, revaluations of assets do not just reflect the volatility in equity and bond markets but also in exchange rates. Almost the entire jump in the UK IIP during 2008 can be accounted for by the depreciation of sterling.

As foreign assets are expressed in foreign currency, depreciation of sterling against that foreign currency means that the valuation of that asset in sterling terms increases. If UK liabilities (UK assets held by foreigners) are valued in sterling then there is no change following depreciation. But were they also valued in foreign currency then the sterling value of liabilities would also rise following depreciation. However this is generally not the case. The majority of UK foreign 
assets will be valued in foreign currency and the majority of UK assets held by foreigners will be valued in sterling so sterling depreciation improves the IIP and sterling appreciation deteriorates the IIP.

Given that the trade-weighted effective sterling exchange rate fell by about 25 per cent during 2008 and the stock of foreign assets held by UK residents amounts to 4 and a half times GDP then it is quite plausible to explain how such a large jump in the IIP was possible. The jump in the value of foreign assets can be seen in Figure 3 as well as in the IIP in Figure 4.

\section{International Investment Position and net investment income}

Until last year (2008) the declining UK IIP was a curiosity in that net international investment income continued to be positive (see Figure 5) - suggesting that an increasingly negative net asset position was managing to create robust positive net investment income ${ }^{3}$. An explanation for the divergence in IIP and net investment income requires the data in Figure 5 to be broken down into the contributions by each type of asset.

Starting with net investment income, Figure $\mathbf{6}$ presents a breakdown by three main asset classes: direct investments, equity investments and other investments which are predominately interest bearing financial assets including debt securities. Surpluses

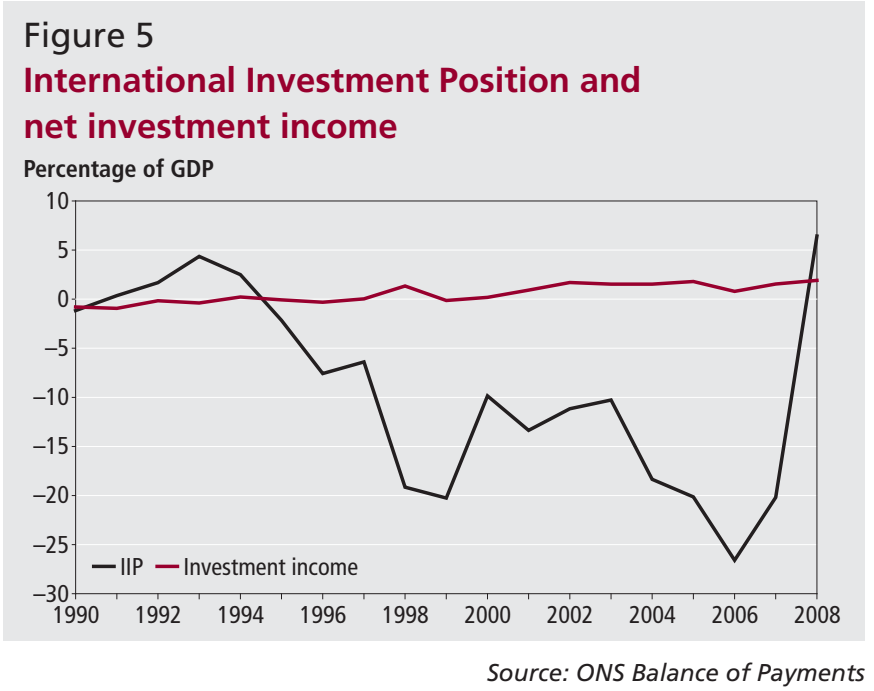

\section{Figure 6}

\section{Breakdown of investment income by asset type}

Percentage of GDP

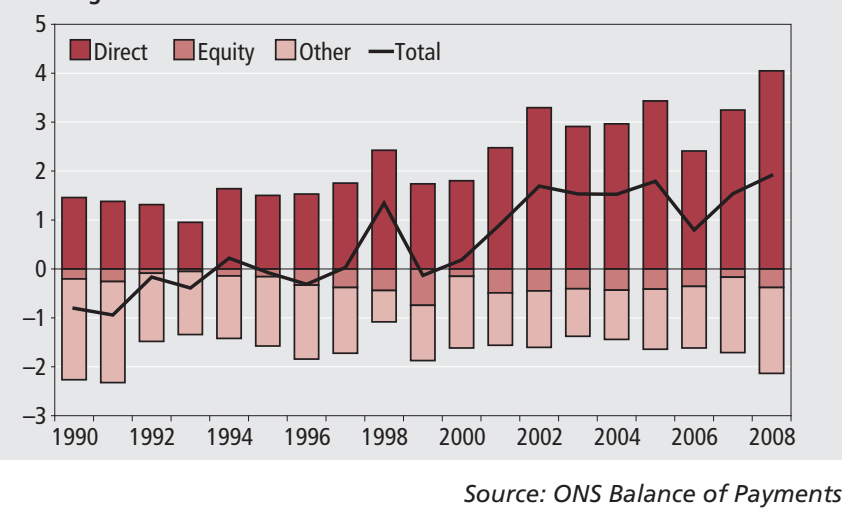

on the investment income balance have clearly been driven from direct investment, while the other two asset classes make negative contributions.

Figure 7 presents the composition of the UK IIP according to the same asset categories. Although the aggregate IIP is generally in deficit, primarily due to the contribution of other investments, the UK has managed to sustain a robust surplus in direct investment assets.

For a negative IIP to generate a surplus in net investment income it must be the case that the UK's stock of foreign assets are generating higher returns than the stock of UK assets held by foreigners. This is confirmed in Figure 8. Rates of return ${ }^{4}$ on the UK's foreign assets and liabilities have generally fallen since the early 1990s in line with global interest rates, but since the mid 1990s the UK has enjoyed a distinct rate of return advantage. It is this that accounts for the positive investment income despite the overall negative position on the IIP.

Figure 9 , by presenting rates of return for each asset class, ties together the trends in Figures 6, 7 and 8. There are a number of observations that can be made:

- Rates of return in direct investment can be volatile, reflecting the global economic cycle, but on the whole exceed those of other asset classes. This differential has grown in the last

\section{Figure 7 \\ IIP breakdown by asset type}

Percentage of GDP

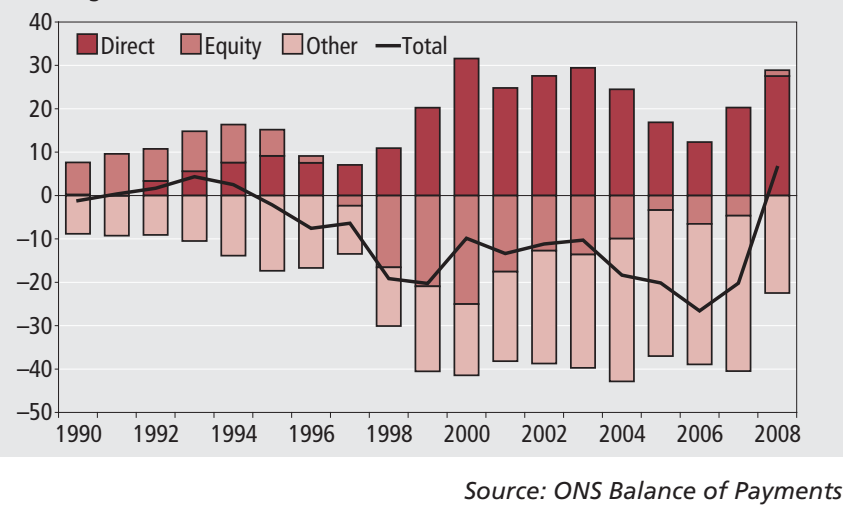

Figure 8

Rates of return on UK assets and liabilities Per cent

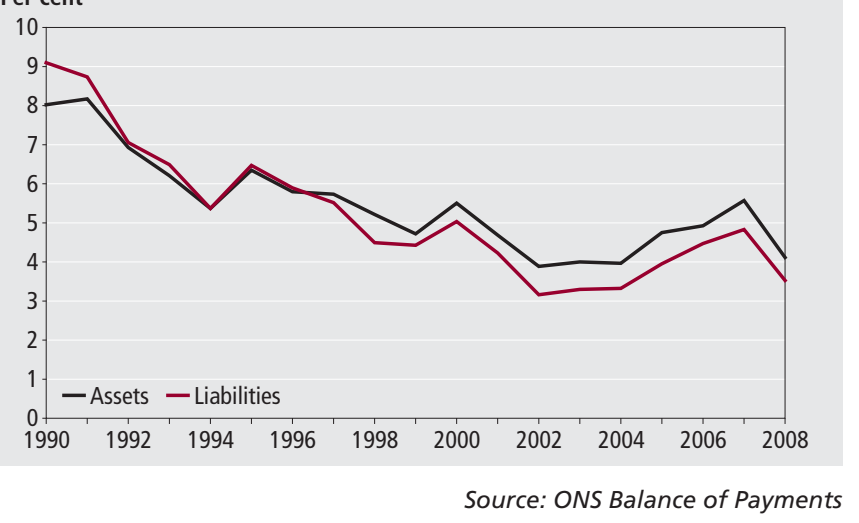




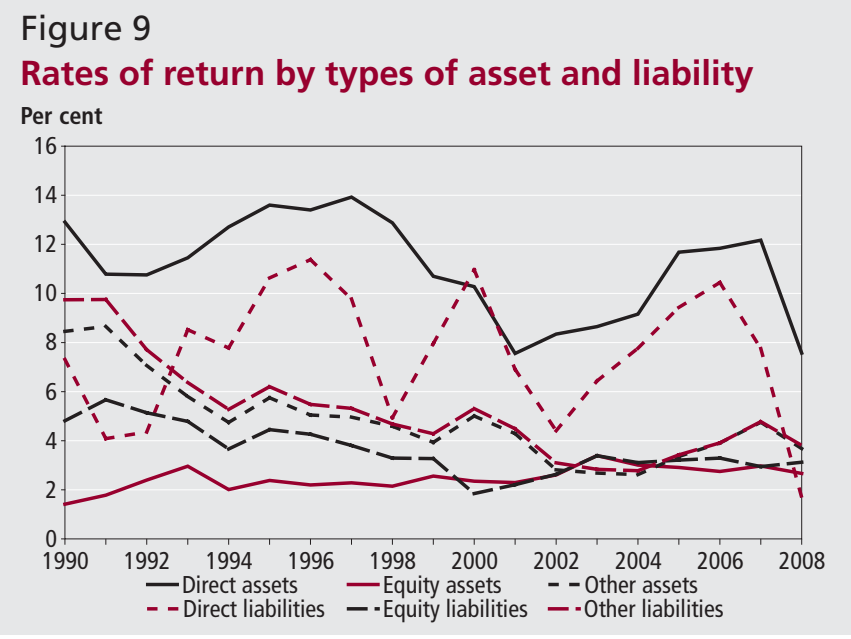

Source: ONS Balance of Payments

decade as the fall in global interest rates pushes down on income from other investments including debt securities which are predominately interest bearing.

- Direct investments, which include equity holdings of over 10 per cent of an enterprise, offer far higher rates of return than smaller equity investments (minority shareholdings). This implies that exercising some degree of control over the enterprise including the power to influence dividend payments yields a superior return.

- Returns on UK held foreign direct investments have generally exceeded those of foreign direct investments into the UK, while there is little rate of return difference in equity and other assets.

Therefore the UK's rate of return advantage is down to two factors.

First, it has a strong net-asset position in higher yielding direct investments. In this respect Nickell (2006) describes the UK IIP as similar to a successful venture capitalist by borrowing cheap interest bearing funds through its negative IIP in other investment assets and maintaining a surplus in its IIP of more lucrative direct investment assets.

Second, even within the direct investment category the UK has a rate of return advantage. In addition to the successful venture capitalist argument that the UK is just relatively good at picking profitable FDI opportunities three other explanations for this advantage have been suggested.

The US also enjoys a rate of return advantage in FDI, which Hausmann and Sturzenegger (2006) put down to exports of 'dark matter ${ }^{5}$. These are the unseen intangibles (or knowledge capital) such as managerial expertise, organisational structure, brand names, IT systems, design and technical (R\&D) capabilities that usually accompany direct investments and make it more successful. The same reasoning may also apply to the UK - that its direct investments abroad are supported by significant transfers of quality intangibles. This reasoning may also account for the rate of return advantage of direct investments over smaller equity investments.

Another explanation is that, for one reason or another, foreigners may be prepared to accept a relatively lower rate of return on their direct investments in the UK. It might be considered as a price for accessing the large EU market allowing firms to benefit from economies of scale in production. The UK is also considered to be a less risky environment in which to do business than other economies, mainly due to the superior development of its legal and financial institutions. As a result the risk premium and yields on inward FDI to the UK would be correspondingly lower.

It might also be the case that firms deliberately report lower profits on their UK operations to reduce tax liabilities of the UK. As the production process becomes more vertically integrated across borders it gives firms scope to move profits through transfer pricing (also known as toll processing). For example, if the UK was considered a relatively high tax country then companies would face an incentive to reduce their reported earnings in the UK. This could be achieved by raising the internal prices of the output produced downstream, or reducing the prices charged upstream, as either would squeeze the margins on UK operations relative to the parts of the production process undertaken in other countries.

Finally, the rate of return on UK direct investments abroad may be exaggerated by underestimating the value of these direct investments and hence the overall IIP. Most financial assets such as equity and debt securities are frequently traded so can be valued using established market prices. Direct investments though are large, unique and illiquid assets for which market prices do not exist and the actual value can differ significantly from book or historic values - making life difficult for statisticians. As a result an undervaluation of the value of direct investment abroad would lead to an overstatement of the rate of return. But it should also be acknowledged that the same argument could be applied to inward foreign direct investment, so this reasoning would require an explanation why direct investment abroad is more likely to be undervalued than inward direct investment.

This analysis also gives insight into the sustainability of the UK's positive investment income balance. As it is primarily generated through direct investment it is important that the UK maintains its net asset position in this asset type. And given that the UK's net asset position has been built up over many years (see Figure 10) it is unlikely to be reversed in the short term. However, direct investment earnings are cyclical and the current global recession appears to be putting downward pressure on income. Furthermore, much of the rate of return advantage enjoyed by the UK has resulted from falling global interest rates making it easier to fund its large negative IIP in other (predominately interest bearing) assets. So should global interest rates start to push upwards it would put downward pressure on UK net investment income.

\section{Recent trends in the UK Balance of Payments}

In this final section more recent trends in the UK Balance of Payments are analysed. These are of special interest given the global nature of the current recession and financial crisis.

Figure 11 shows, as a percentage of GDP and on a quarterly basis, the main component parts of the UK Current Account. Most striking is that since the beginning of 2008 the UK Current Account deficit has grown, despite the balance of trade (goods and services) improving. Transfers have been very stable, so the deterioration over the last year has been primarily driven by falling net investment income. 


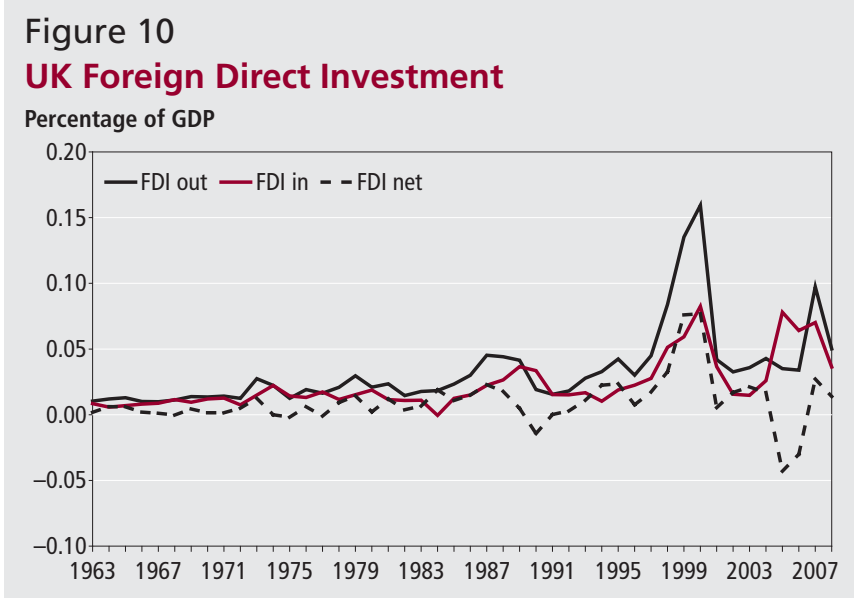

Source: ONS Balance of Payments

\section{Figure 11}

\section{Current Account}

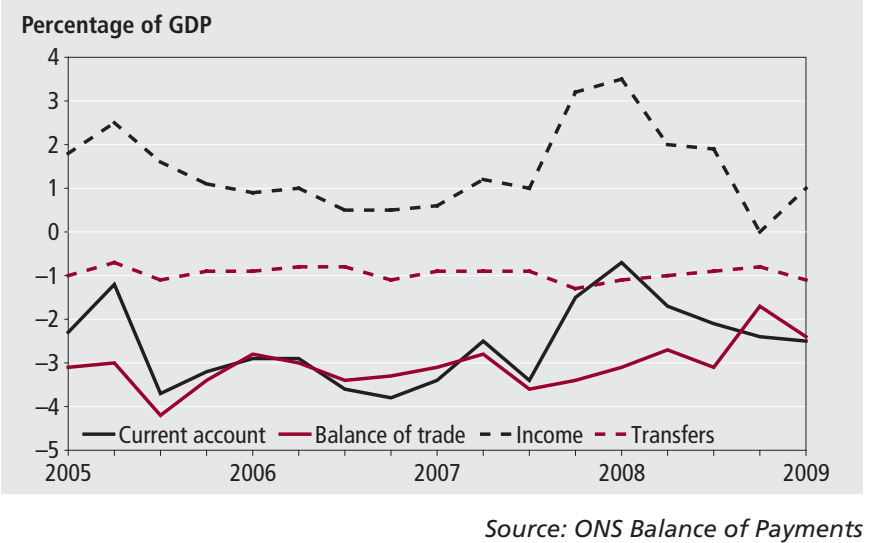

In Figure 12 the exports and imports of goods are presented. As most of the balance on goods trade is determined by manufactures (semi and finished goods) then both exports and imports have fallen quickly as a result of the global economic downturn being concentrated in the manufacturing sector. However, because UK imports have fallen faster than exports the overall goods deficit has narrowed in recent quarters.

Services trade though has been relatively robust through the recession. In fact, as Figure 13 shows, there has been no notable downturn as a proportion of GDP and the overall UK balance has improved. One area that appears to have been doing well is the financial sector, ironically as a result of the global financial crisis.

Financial sector output consists of two main parts. First there are activities for which fee and commission income is earned, and as expected, this has fallen in line with business activity in the global recession. These are direct outputs, known as Financial Intermediation Services Directly Measured (FISDM). However, much of the output of the financial services sector is not charged for directly, such as current account services. Here incomes are usually made by a spread between deposit (savings) and credit (lending) rates - this output is known as Financial Intermediation Services Indirectly Measured (FISIM). One of the consequences of the financial crisis is that these spreads have widened. Central banks around the world have been aggressive in cutting interest rates which have been passed on quickly into deposit rates. But lending rates have come down less quickly, and for many consumer loans they

\section{Figure 12}

Trade in goods

Percentage of GDP

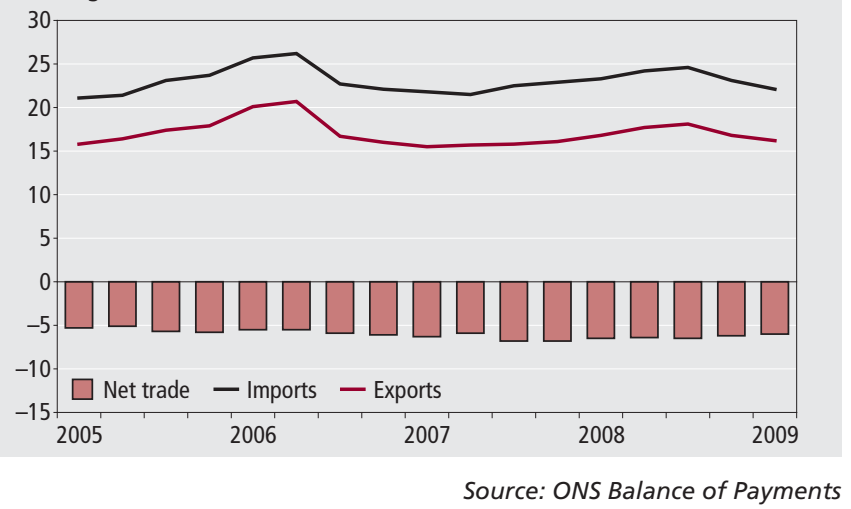

Figure 13

Trade in services

Percentage of GDP

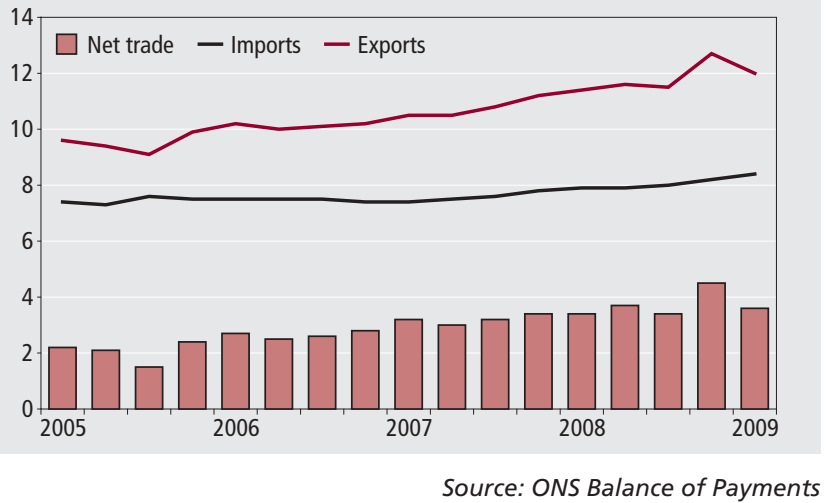

have actually not come down at all or gone up - a reflection of the banking sectors updated view on risk and their desire to cut back on some lending. Given that the deposit base hasn't changed that much this has led to a large jump in calculated FISIM output in the last year. And because the UK financial services sector is large and operates on a global scale it is likely that FISIM exports will have increased as well.

Net investment income though, despite continuing to make a positive contribution to the Current Account, has fallen sharply in recent quarters. Although it must also be acknowledged that net income had been particularly strong in 2007 , so much of the reversal may just be trend correcting. Strong investment income was the main factor closing the Current Account in early 2008, and has been the main factor in the widening deficit thereafter.

Given the UK's strong net asset position in direct investment, most of the deterioration can be traced to this asset class. Earnings on direct investment abroad, and on foreign earnings on direct investments in the UK have fallen, mostly likely as a consequence of the global recession and credit crunch on company profits. Particularly affected are the earnings of financial corporations. As direct investment in the UK from overseas are highly concentrated in the banking sector it explains why income flows out of the UK have fallen faster than flows to the UK in recent years.

As explained already, Capital and Financial Account transactions are the mirror of Current Account transactions. Hence the deterioration 


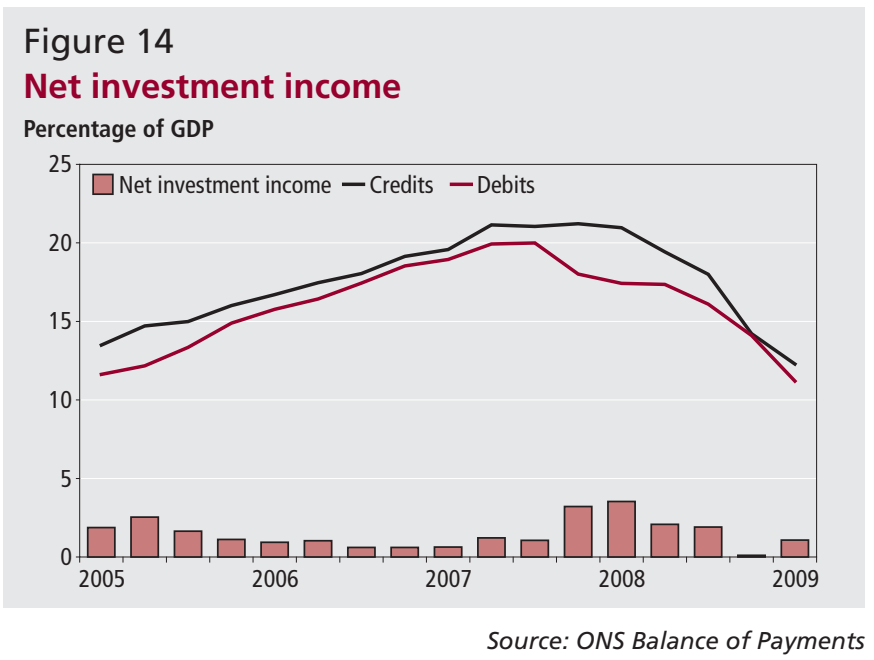

Figure 15

\section{Financial Account transactions}

Percentage of GDP

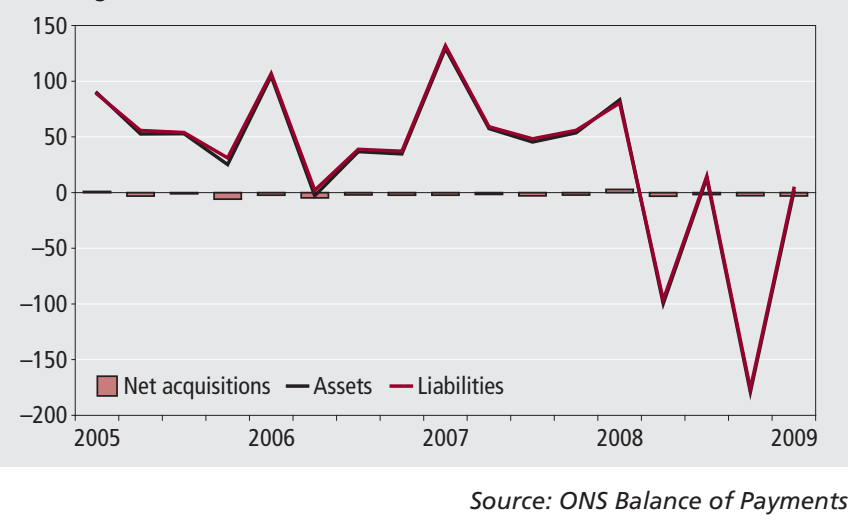

in the Current Account would be associated with a growing surplus on the Capital and Financial Accounts as the UK reduces its netasset position vis-à-vis the rest of the world.

However, it is still worth looking at because while the balance may actually be quite small, there have been very large recent movements in the flows of financial assets. This is shown quite clearly in Figure 1, where the UK's cross-border accumulation of financial assets and liabilities was massively negative in 2008 .

The quarterly figures underline the recent volatility in financial markets (see Figure 15). The striking feature which is also picked up in Figure 1 are the periods of large disinvestment - where UK residents cut back on their stocks of foreign assets and foreign residents on their stocks of UK assets. This could be to reduce more 'risky' holdings of foreign assets or simply to repatriate assets to cover domestic losses and shore up balance sheets. For example, securities have been one of the financial asset classes most affected by the fallout from the US sub-prime mortgage market and the credit crunch and much of the volatility in the UK Financial Account has resulted from disinvestments in these assets. In the past net disinvestment in equities has frequently coincided with financial shocks - for example the UK's exit from the Exchange Rate Mechanism in 1992, the Asian financial crisis in 1997 and the collapse in equity markets in 2002. The most recent crisis though is more unique in that disinvestment has happened across a broad range of asset classes, not just the more volatile ones.

\section{Notes}

1. Much of this article follows and updates the analysis in Nickell (2006).

2. Chamberlin (2008) provides further evidence on the shifting composition of UK output and trade including its implications for the terms of trade.

3. Similar analysis and background on the UK International Investment Position can be found in Nickell (2006) and Whitaker (2006).

4. The rate of return on an asset in time $(t)$ is calculated as the income generated by the asset in time $(\mathrm{t})$ divided by the stock of asset in time (t-1).

5. More on the US Balance of Payments and the subject of 'dark matter' can be found in Chamberlin (2009).

\section{CONTACT}

凶)elmr@ons.gsi.gov.uk

\section{REFERENCES}

Chamberlin G (2008) 'Command GDP: the purchasing power of UK output', Economic and Labour Market Review (September)

Chamberlin G (2009) 'Dark matter. Does it matter?' in Linda Yueh (ed) 'The law and economics of globalisation', Edward Elgar

Hausmann R and Sturzenegger F (2006) 'Global imbalances or bad accounting? The missing dark matter in the wealth of nations', Centre for International Development, Harvard University, Working Paper no. 124, January

Nickell S (2006) 'The current account and all that', Bank of England Quarterly Bulletin Summer

Whitaker S (2006) 'The UK international investment position', Bank of England Quarterly Bulletin 2006 Q3 